International Journal of Industrial Engineering and Management (IJIEM), Vol. 9 No 3, 2018, pp. 155-166

Available online at www.iim.ftn.uns.ac.rs/ijiem_journal.php

ISSN 2217-2661

http://doi.org/10.24867/IJIEM-2018-3-155

\title{
Knowledge Analysis on Logistics Cost Trade-Offs: a Study With Portuguese Food Sector' Professionals
}

\author{
Ana Luiza Cordeiro Pereira \\ Graduate Student, Instituto Federal de Educação, Ciência e Tecnologia de Minas Gerais, 3007, Michael Pereira de Souza \\ Avenue, Campinho, Congonhas, Brazil, analuizacordeiro96@gmail.com
}

Alexandra Manuela Novais Almeida dos Santos Martins

CIDEM- Centro de Investigação e Desenvolvimento em Engenharia Mecânica/Instituto Superior de Engenharia do Porto, 431, Dr. António Bernardino de Almeida Street, Paranhos, Porto. Portugal, 1160008@isep.ipp.pt

\section{Renata Veloso Santos Policarpo}

Instituto Federal de Educação, Ciência e Tecnologia de Minas Gerais, 3007, Michael Pereira de Souza Avenue, Campinho, Congonhas, Brazil, renataveloso@ifmg.edu.br

\section{Maria Teresa Ribeiro Pereira}

CIDEM- Centro de Investigação e Desenvolvimento em Engenharia Mecânica/Instituto Superior de Engenharia do Porto, 431, Dr. António Bernardino de Almeida Street, Paranhos, Porto. Portugal, mtp@isep.ipp.pt

Received (16.05.2018.); Revised (29.06.2018.); Accepted (03.09.2018.)

\begin{abstract}
Logistics is an important area in the economic-financial performance of companies, which makes it necessary to analyse their costs, as well as the trade-offs between them. Thus, the present study, with the objective of analysing the Portuguese food sector logistic professionals' knowledge regarding to logistics costs trade-offs and their impact on the economic-financial performance of the organizations, showed that there are gaps concerning this subject. Throughout the structured interview and by using the SPSS software, the study shows the existence of flaws in the practical application of the trade-offs' theory, such as the pressure from the managers for individual cuts in costs; and points out trade-offs of logistical costs relevant to the food sector. These results contribute to the expansion of studies on the subject, besides providing a perspective of the compensatory exchanges that can contribute to the decision making in relation to the costs concerning logistics activities.
\end{abstract}

Key words: logistics costs; logistics costs trade-offs; economic-financial performance; food sector; food logistics.

\section{INTRODUCTION}

Optimization of systems and costs is today one of the most important factors for companies to become competitive (Ketchen and Hult, 2007; Bhatnagar and Téo, 2009). Rao and Holt (2005) and Zhu et al. (2013) agree that the adoption of supply chain management practices will ultimately translate into profitability and improved financial performance. In view of this, the importance of good logistical management is highlighted, since it assists in the determination of revenues, costs and the use of fixed and working capital (Richardson, 1993; Christopher and Ryals, 1999; Walters, 1999; Ptresutti and Mawhinney, 2007). Logistics activities despite adding time and place values to products and services, are important in generating costs to the company (Ballou, 2006; Pozo, 2016; Christopher, 2016; Bowersox et al., 2014; Gunasekaran and Kobu, 2007). Koscielniak (2011) and NowakowskaGunt and Новаковска-Грунт (2013) affirm that logistics costs are a specific type of costs caused by planning, controlling and implementing the process of displacing materials and products considering the time and space. Besides, Stępień et al. (2016) call attention to the possibility of cost reduction through logistics.

In the process of optimizing logistical costs, the need to analyse their trade-offs arises, that according to Amaral and Guerreiro (2014), refers to the compensatory exchange between the loss in some aspect and the gain in another one also related to the logistics chain. Lambert and Armitage (1979) argue, in order to effectively optimize total logistical costs, it is necessary, once the level of customer service is established, logistics costs are minimized in an integrated way. Mclntyre and Ryans (1983) further add that individual cost cuts can increase rather than reduce total cost.

In this sense the present study aims to analyse the logistics professional's knowledge in the food sector about the logistics costs trade-offs and their influence in the Portuguese companies economic-financial 
performance. To carry out the study, two questions were formulated: "What are the most emphasised logistics costs trade-offs by the food industry?" and "Do logistics professionals really know what are the tradeoffs of logistics costs?". In addition, two hypotheses were formulated: "The search for momentary results collaborate for the non-application of the theory of trade-offs in companies in relation to logistic activities" and "The term 'trade-offs of logistics costs' is still little used in food companies". The present study was organized as it follows: in the present section an introduction is made; section 2 is a literature review, which embraces logistics costs, logistics costs tradeoffs and logistics management importance for economic-financial performance in the food sector; in section 3 the methodology is presented; in section 4 the results are presented; and in section 5, final considerations and future work are highlighted.

\section{LITERATURE REVIEW}

\subsection{Logistics costs}

According to the Council of Logistics Management, logistics is part of the supply chain management that plans, implements, and controls the forward and reverse flow and storage of goods, services, and related information between the point of origin and the point of consumption to serve customers efficiently. According to Ballou (2009) the logistic is composed by important activities which add value to time and place, such as: Transportation, Inventory Management, Order Processing, purchasing, Product Programming, Protection Packaging, Material Handling, Storage and Information Maintenance.

Pozo (2016), Christopher (2016), Bowersox and Closs (2001) and Gunasekaran et al. (2007) affirm in their studies that the logistic is one among the many factors generating costs in a company. Stępień et al. (2016) call attention to the possibility of cost reduction through logistics and together with Ketchen et al. (2007) and Bhatnagar (2009) emphasize the importance of reducing costs in order to become competitive. According to Koscielniak (2011) and Nowakowska-Gunt and Новаковска-Грунт (2013) the logistical cost is a specific type of cost caused by plan, control and implementation process of displacement of materials and products in time and space.

Fang and $\mathrm{Ng}$ (2011), Zeng and Rossetti (2003) and Sobotka and Czarnigowska (2005) claim that logistics cost are composed by: costs with transportation of supplies; stocks' maintenance and expiry; manufacturing, warehouse and transport management; interest rates on credits; information and communication costs; risk, handling and packaging costs; and the ones for maintenance of excessive stocks and losses caused by improper material management.Szalek (1994) apud Stępień et al. (2016) affirm that logistics costs can be classified as direct or indirect costs, as well as can be identified as fixed and variable costs; acquisition, production and distribution costs; material and non-material costs; logistical processing costs and, lastly, purely logistical costs.
Stepién et al. (2016) draw attention to complexity in defining and classifying logistics costs among the total costs of an organization. For this, Folta et al. (2013) and Stępień et al. (2016) suggest that logistic costs can be divided by means of some criteria, such as: by type (considering the accounting system); by cost centre (isolated in the accounting system); by the relation with the basic logistic processes, that is, information and material flow and maintenance of inventories; and by volatility relating to the size of the flow of materials or the maintained inventory.

Sanchez et al. (2003) claim that the costs are directly associated to process efficiency. In this sense, Xu et al. (2015) draw attention to the integration of the logistics chain to facilitate its optimization and reduce costs. Graungaard Pedersen et al. (2012) add that the centralized networks enable the efficient use of resources, such as inventory and labour, which according to Chen and Chen (2005) result in lower fixed costs and better adjustment of demand variation. However, Adenso-Diaz et al. (2016) affirm that distributed networks provide excellent customer service and lower transportation costs.

\subsection{Logistic costs trade-offs}

According to Amaral and Guerreiro (2014) trade-off refers to the compensatory exchange between the loss in some aspect and the gain in another aspect. The authors affirm that the trade-offs of logistics costs comprise the compensatory exchanges in which the increase in a logistics cost can be compensated by the reduction in another logistics cost and / or the increase of the service level offered to the customer. Lambert and Armitage (1979) point out that the existence of trade-offs causes isolated cost cuts to be responsible for increasing total cost and reducing the level of customer service.

Furthermore, the objective of assessing trade-offs would be identifying the performance of each logistic component according to proposed actions, to measure the compensations and to choose the alternative that optimizes the total cost and the economic-financial performance.

Castiglioni and Nascimento (2014) argue that one of the main trade-offs of a logistics system is providing a higher level of service without resulting in a substantial increase in the costs of the organization. Blecic et al. (2007) emphasize in their studies the importance of the trade-offs between the level of service and the costs of maintenance of inventories, one of the main activities of logistics. De Jong et al. (2016) also draw attention to the trade-offs between time and transport costs, which according to Hensher and Puckett (2008) are the main variables explaining the choices of the receivers, especially when it comes to products with short-term transport.Amaral and Guerreiro (2014) emphasize, in turn, the trade-offs present between inventory maintenance and transport activities, and the costs related to the two activities are the most relevant in proportion to the total logistics costs. Jackson et al. (1994) explain that as the stock is reduced, transportation costs increase because smaller 
quantities are sent more frequently. However, as transportation costs are reduced due to transportation in larger quantities, inventory levels in the system increase. Thus, the analysis of total costs requires that all relevant costs shall be quantified and analysed and that all actions are taken to minimize the total costs of the system.

That is, in case of conflict, one must choose the solution which allows the lowest total cost. Kator (2007), Chow (2008), Murphy and Poist (2007) argue that the tradeoffs between the above-mentioned activities are relevant to the analysis of the logistical network design, and these areas are important for the logistics skills required by the managers.Janssen (2004) and Torabi et al. (2015), through their research, point out the importance of analysing logistics cost trade-offs and affirm that, for companies to succeed, all organizations involved in the supply chain must have precise knowledge and analyse the trade-offs to better control logistical activities and, consequently, reduce their costs, which according to Bowersox et al. (2014) are relevant to the total costs of an institution.

Through their studies, Cheong and Song (2013) emphasize that an accurate logistics, even if impacting on costs, can ensure system reliability, add value, and potentially increase profits, thus characterizing an important trade-off to be analysed.

\subsection{Logistic management importance for economic-financial performance in food sector}

Sum et al. (2004) affirm that a company's high economic performance is the result of good business, with operational support in materials, product design and support services. They also point to performance measures, such as: global financial performance, annual sales growth, market share growth, return on sales, return on investments, growth in investments. According to Cerchione and Esposito (2016), economic and financial performance growth require good management of the various activities related to the productive system. Rao and Holt (2005) and Zhu et al. (2013) agree that the adoption of supply chain management practices will ultimately translate into profitability and improved financial performance. In view of this, the importance of good logistical management is highlighted, since it assists in the determination of revenues, costs, the use of fixed and working capital (Richardson, 1993; Christopher and Ryals, 1999; Walters, 1999; Ptresutti and Mawhinney, 2007).

Lambert and Armitage (1979) argue that integrated logistics management made it even more necessary to analyse the impacts of logistics costs on economic and financial performance. According to Mentzer, Flint and Hult (2001), logistics activities are determinant for the sales cycle to be accomplished, since they enable fast and complete replenishment of stocks, facilitate the fulfilment of customer needs, allow access to items and ensure the availability of current portfolio and future releases.

Esper et al. (2010), Hult et al. (2006), Lakshman and Parente (2008), Liu et al. (2012) and Yang et al. (2009) through their studies emphasize that the integration and ability to share knowledge among the areas allow for greater speed, quality and flexibility, as well as reducing costs, factors that contribute to the performance of organizations.

Randall and Farris (2009) affirm that a collaborative supply chain management strategy enables increased profitability for all members of the chain, since actions as shifting inventories, implementing supply chain financing techniques with important partners increase revenues and reduce costs. Walters (2004) argue that the overall rate of return on investment increases when there are partnerships in the supply chain characterized by trust, cooperative flow management, and shared cost of capital.Regarding the food sector, Marçal (2006) affirms that in the food follow-up some aspects shall be considered as competitive factors: services and logistics support, considering that it is increasingly determinant to satisfy the customer in an effective way, which is to facilitate the delivery of the products in a simplified way, to serve with agility; quality of products, and this is a consequence of consumers' demand to purchase higher quality products, both nutritional and as regards conservation conditions; price, which is shown as a determining factor, since the customer has a wide variety of suppliers; new forms of business are important to ensure competitive advantage; crucial for the food sector, since quality, food safety, and speed of delivery are consumer demands for food products; and finally, the variety and innovation of products, with customers' choices increasing and more varied, and strong competition is in itself a determining factor in ensuring that the customer is always satisfied.

The importance of logistics for the food sector is therefore inferred since the related activities are linked or are directly responsible for the guarantee of the factors just highlighted, which according to the author mentioned previously are determinant for the success of the segment

This fact, together with the representativeness of logistics costs in relation to total costs, allow us to affirm that the study and optimization of costs related to logistics is crucial for the companies emphasized in the research.

\section{METHODOLOGY}

The present study consists of qualitative-quantitative research. Qualitative research is associated with the collection and analysis of text (spoken and written) and direct observation of behaviour (Moreira, 2002). Quantitative research, in turn, is about quantifying data or opinions in the forms of information collection, and statistical resources, furthermore, techniques can be used (Oliveira, 2001). The data collection was performed by the application of the structured (or closed) interview, which according to Craig (1991) is composed of a certain set of questions about defined areas of content, necessarily foreseen and ordered (Bleger, 1971). According to Selltiz et al. (1974) the interview is an adequate technique for obtaining information regarding to what people know, believe, expect, feel or desire, intend to do or have done. This data collection instrument was chosen, considering the 
study objective of analysing the knowledge about logistics costs trade-offs of logistics professionals in the Portuguese food sector. The interview script in question was developed based on literature review as well as based on the studies of Amaral (2012), which provides the theoretical and experimental basis for answering the research questions and satisfying the objectives of the study. The literature review was based on studies of logistics costs, logistical cost trade-offs and economicfinancial performance, to create a solid conceptual theoretical basis. The interview script used consists of twenty-nine questions divided into five main sections: knowledge about the logistics professional and the company in which it operates, structuring the logistics area, outsourced logistics activities, knowledge about the logistics costs trade-offs and analysis and evaluation of possible logistics costs trade-offs. It is important to emphasize that the questions presented in the present study are the most significant ones considered in the logistics costs trade-offs issue, not all the questions will be presented in the table below nor in the analysis made in the results. The validation of the research instrument was carried out between March and May 2017, by an experienced professional in the logistics area, who holds the position of export manager in a Portuguese company. After validation, the researchers were interviewed through an online survey, eighteen logistics professionals, each from a different Portuguese food company.

The contact with the professionals was possible due to the collaboration of a Portuguese food sector association. Table 1 shows the issues emphasized in this article, as well as the reason it was done and the authors that gave rise to the questioning, when applicable. The data collected were then treated statistically with the help of the IBM SPSS Statistics software version 24 . The results are presented below.

\section{RESULTS}

As discussed previously, the data were treated by the IBM SPSS Statistics 24, and it is important to emphasize that the ranges of the answers covered in the response options that were not selected by any of the professionals, that is, that they had $0 \%$ significance in the answers, were not considered in the analysis made below. The first analyses made concern information about the professionals and the companies in which they work. The Table 2 shows the professionals time of experience, it can be seen that most of the professionals work in the logistics area for more than six years, with $33.3 \%$ of them working from six to ten years, $16,7 \%$ work in a period between 11 and 15 years, and $27.8 \%$ work in the logistics area for sixteen or more years. On this, Slone et al. (2007) emphasize the need for knowledge of logistics within organizations and emphasize that this knowledge can be formally constituted, by courses, or, informally, by experience, which broadens the functional background and the number of situations previously experienced, which facilitates in the decision making and makes possible the good management of the activities.
Table 1.1 Questions, reasons and authors

\begin{tabular}{|c|c|c|}
\hline Statement & Reason for question & $\begin{array}{l}\text { Theoretical } \\
\text { background }\end{array}$ \\
\hline \multicolumn{3}{|c|}{$\begin{array}{l}\text { Section one: Knowledge about the logistic professional and the } \\
\text { company in which it operates. }\end{array}$} \\
\hline $\begin{array}{l}\text { Logistics experience } \\
\text { time }\end{array}$ & $\begin{array}{l}\text { Identification of the } \\
\text { professional experience } \\
\text { in the area and } \\
\text { consequence on their } \\
\text { knowledge about trade- } \\
\text { offs of logistics costs. }\end{array}$ & $\begin{array}{l}\text { Myers; Griffith; } \\
\text { Daugherty; } \\
\text { Lusch (2004); } \\
\text { Slone; Mentzer; } \\
\text { Dittmann (2007). }\end{array}$ \\
\hline Academic education & $\begin{array}{l}\text { Identification of the formal } \\
\text { education of the } \\
\text { professional and } \\
\text { consequence on his } \\
\text { knowledge about the } \\
\text { trade-offs of logistic } \\
\text { costs. }\end{array}$ & $\begin{array}{l}\text { Myers et al. } \\
(2004) \text {. }\end{array}$ \\
\hline $\begin{array}{l}\text { Positions held in the } \\
\text { company }\end{array}$ & $\begin{array}{l}\text { Identification of the } \\
\text { hierarchical position of } \\
\text { the professional, that is, } \\
\text { of the degree of } \\
\text { responsibility in the } \\
\text { decision making. }\end{array}$ & Fellous (2009) \\
\hline Nature of business & $\begin{array}{l}\text { Characterization of the } \\
\text { company in which it } \\
\text { operates. }\end{array}$ & $\begin{array}{l}\text { Souza; Rocha } \\
(2009) \text {. }\end{array}$ \\
\hline Turnover in 2016 & $\begin{array}{l}\text { Identification of the size } \\
\text { of the business, that is, of } \\
\text { relevance to the sector. }\end{array}$ & Fellous (2009). \\
\hline
\end{tabular}

Section two: Structuring the logistics area.

\begin{tabular}{l|l|l|}
$\begin{array}{l}\text { Does the company in } \\
\text { which you operate } \\
\text { have a specific area } \\
\text { responsible for } \\
\text { logistical and / or } \\
\text { supply chain } \\
\text { management? }\end{array}$ & $\begin{array}{l}\text { Identification of the level } \\
\text { of formalization of the } \\
\text { logistics area in the } \\
\text { company in which it } \\
\text { operates. }\end{array}$ & $\begin{array}{l}\text { Chow et al. } \\
(1995)\end{array}$ \\
\hline $\begin{array}{l}\text { Among the activities } \\
\text { below, select those } \\
\text { that belong to the }\end{array}$ & & \\
$\begin{array}{l}\text { scope of logistics } \\
\text { management of the } \\
\text { company in which it } \\
\text { operates }\end{array}$ & $\begin{array}{l}\text { Characterization of the } \\
\text { scope of the logistics } \\
\text { area of the organization } \\
\text { in which it operates. }\end{array}$ & $\begin{array}{l}\text { La Londe et. al } \\
\text { (1976); Chow et } \\
\text { al. (1995); Ballou } \\
\text { (2006); Fellous } \\
\text { (2009); }\end{array}$ \\
\hline \multicolumn{2}{|l|}{}
\end{tabular}

Section three: Outsourced logistics activities.

\begin{tabular}{|c|c|c|}
\hline $\begin{array}{l}\text { nong the activities } \\
\text { lated to logistics } \\
\text { anagement } \\
\text { lentioned in the } \\
\text { evious question) are } \\
\text { ere outsourced } \\
\text { tivities, that is, that } \\
\text { e not the } \\
\text { sponsibility of the } \\
\text { mpany itself? }\end{array}$ & $\begin{array}{l}\text { Identification of the level } \\
\text { of centralization of } \\
\text { logistics activities by the } \\
\text { company. }\end{array}$ & $\begin{array}{l}\text { Christopher; } \\
\text { Juttner, 2000, } \\
\text { Pires (2004); } \\
\text { Kremic et al. } \\
\text { (2006) Quélin e } \\
\text { Duhamel } \\
\text { (2003),Lieb e } \\
\text { Randall (1996), } \\
\text { Boyson et al. } \\
\text { (1999), Costa et } \\
\text { al. (2002), Wong; } \\
\text { Sohal (2002), } \\
\text { Novaes (2004) } \\
\end{array}$ \\
\hline & $\begin{array}{l}\text { Identification of the level } \\
\text { of centralization of } \\
\text { logistics activities by the } \\
\text { company. }\end{array}$ & $\begin{array}{l}\text { Pires (2004); } \\
\text { Kremic et al. } \\
\text { (2006) Quélin e } \\
\text { Duhamel (2003); } \\
\text { Lieb e Randall } \\
\text { (1996); Boyson } \\
\text { et al. (1999); } \\
\text { Costa et al. } \\
\text { (2002); Wong; } \\
\text { Sohal (2002); } \\
\text { Novaes (2004); }\end{array}$ \\
\hline
\end{tabular}


Table 1.2 Questions, reasons and authors

Section four: Knowledge about the logistics costs trade-offs.

\begin{tabular}{|l|l|l|}
\hline & & $\begin{array}{l}\text { Richardson } \\
\text { (1993); Johnson } \\
\text { Is it propagated in the }\end{array}$ \\
company in which it & & Christopher; \\
operates that logistics & Identification of the & Ryals (1999); \\
and related costs & professional's degree of & Walters (1999); \\
impact the & knowledge about the & Ballou (2006); \\
organization's financial & impacts of logistics on the & Presutti; \\
economic & company's economic and & Mawhinney \\
performance? & financial performance. & (2007); \\
\hline
\end{tabular}

Due to the existence of compensatory cost

changes, the increase

in the cost of a given

logistics activity may be

offset by the increase

in revenues because of

the increase in the

level of customer

service or the reduction

in the cost of another

logistics activity, and

vice versa. Is this idea

propagated in the

organization in which it operates?

degree of knowledge of

the existence of log-cost trade-offs.

Identification of the

degree of knowledge of

the relationship between

cost trade-offs and total

cost.

which it operates?

which it operates?

Does the idea that

individual cost

reduction can generate

an increase in total

logistic cost is

widespread in the

company in which it

operates?

Is it possible to

perceive in the day-to-

day business of the

organization in which it

works some type of

pressure by individual

cost cuts that generate

increase of the total

logistic cost or worsen

in the level of service

offered to the client?

Identification of the

existence of business

situations in which

individual costs are not

managed in favor of the

lowest total cost or better

level of service.

Tyndall; Busher

(1985); Lambert; Armitage (1979)

Section five: Analysis and evaluation of possible logistics costs tradeoffs

Indicate the

compensatory

exchanges considered

relevant for the

organization in which it

operates, that is, those

that are analysed more

frequently and have a

greater impact on

economic and financial

performance:

\begin{tabular}{|l|} 
\\
Identification of the most \\
relevant trade-offs on the \\
economic-financial \\
performance and \\
consequently analysed \\
more frequently in the \\
company.
\end{tabular}

Lambert;

Armitage (1979);

Wanke et. al

2010)

Christopher

(1997); Bio;

Robles; Faria

(2002); Faria

(2003); Fellous (2009);

Lambert;

Armitage (1979):

Lambert;

Armitage (1979)

Lewis; Culliton;

Steele (1956);

Christopher

(1994); Gopal e

Cypress (1993).

Table 2. Time of professional experience

\begin{tabular}{ll|l} 
& Frequency & Percentage \\
\hline Up to 2 years & 2 & 11.1 \\
\hline $3-5$ years & 2 & 11.1 \\
\hline $6-10$ years & 6 & 33.3 \\
\hline $11-15$ years & 3 & 16.7 \\
\hline 16 or more years & 5 & 27.8 \\
\hline Total & 18 & 100.0 \\
\hline
\end{tabular}

Amaral (2012);

Dornier et al. (2000); BIO et al. (2004)
As already mentioned previously by Slone et al (2007) and Amaral and Guerreiro (2014), one of the effective ways of obtaining knowledge is through studies and courses, which characterizes the professional's academic formation.

When analysing this characteristic of the professionals considered here, it is noticed that the majority share has at least higher education, $50 \%$ have undergraduate education, $16.7 \%$ also have MBA specialization and $11.1 \%$ have already undergone the course of masters or doctorates (Table 3).

Table 3. Academic formation

High school / technical

Higher education

Specialization / MBA

Master's / Doctoral degree

Total

Frequency Percentage

\begin{tabular}{l|l}
\hline 4 & 22.2 \\
\hline 9 & 50.0 \\
\hline 3 & 16.7 \\
\hline 2 & 11.1 \\
\hline 18 & 100.0 \\
\hline
\end{tabular}

The next analysis to be made concerns the position occupied by the professional in the organization which he provides his services. Although companies are increasingly seeking for decentralization level for decision-making, where there is an increase in the level of participation of the groups and the autonomy for their members to perform their functions, the hierarchical level occupied is directly related to responsibility (Hall, 1984; Mintzberg, 1995; Paula, 2007). As shown in Figure 4 and Table 4, most respondents hold the positions of administrator / director or manager of logistics / supply chain, corresponding to $27.8 \%$ each of the hierarchical positions.

It is noteworthy that although some of the positions listed in Table 4 are not specifically active in the logistics sector, they have their activities related to or directed to logistics. It can be said that, in the majority positions, many respondents have a high level of responsibility towards the logistics system of the organization.

Table 4. Positions held in the company

\begin{tabular}{llll} 
& Frequency & Percentage \\
\hline Director & 5 & 27.8 \\
\hline Logistics / Supply Chain Manager & 5 & 27.8 \\
\hline Operation Manager & 4 & 22.2 \\
\hline Owner & 3 & 16.7 \\
\hline Others & 1 & 5.6 \\
\hline Total & 18 & 100.0
\end{tabular}

Table 5 relates to the businesses nature of the companies in which the interviewed professionals operate. It is noticed that the production of meats and sweets / pastry (bakery) are the majority, with $22.2 \%$ each segment.

Then, we can highlight the production of seasonings / condiments, with $16.7 \%$, followed by the production of drinks, and canned and inlaid, with $11.1 \%$ and finally, grains and cereals, hortifrutigranjeiro and dairy products, with $5.6 \%$ each. 
Table 5. Business type of the companies in which the professionals act

\begin{tabular}{lr|r} 
& Frequency & Percentage \\
\hline Drinks & 2 & 11.1 \\
\hline Meats & 4 & 22.2 \\
\hline Sweets / Pastry (Bakery) & 4 & 22.2 \\
\hline Canned and inlaid & 2 & 11.1 \\
\hline Grains and Cereals & 1 & 5.6 \\
\hline Hortifrutigranjeiro & 1 & 5.6 \\
\hline Dairy Products & 1 & 5.6 \\
\hline Seasoning / Condiments & 3 & 16.7 \\
\hline Total & 18 & 100.0 \\
\hline
\end{tabular}

The last analyses referring to the first section of the questions asked concerns turnover in the year 2016. On this and looking at Table 6 it is inferred that more than $60 \%$ of the organizations in which the professionals interviewed work, had a turnover of more than five million euros in 2016.

Table 6. Turnover in 2016

\begin{tabular}{lr|r} 
& Frequency & Percentage \\
\hline Less than EUR 250,000 & 4 & 22,2 \\
\hline Between $€ 2,500,001$ and $€$ & 3 & 16,7 \\
$5,000,000$ & & \\
\hline Greater than EUR 5,000,000 & 11 & 61,1 \\
\hline Total & 18 & 100,0 \\
\hline
\end{tabular}

The analyses that follow refer to the second section of the questions, which aims to know the structuring of the logistics area of the companies in which the interviewees work. The first analysis of this section concerns to the existence or not of a specific area responsible for logistics management and / or the supply chain. Regarding this, more than seventy percent of the interviewees confirmed the existence of a specific area responsible for the company's logistics activities (Table 7). Logistics is an area of paramount importance to the organization, including in the face of costing, and is still considered by some organizations as an auxiliary activity, however the growth of the emphasis given to it in recent years is noticeable. the existence of a specific area for its management is directly related to the way in which the company deals with logistics activities (Ballou, 2006; Bowersox; Closs, 2009).

Table 7. Existence or not of specific area responsible for supply chain and/or logistics management

\begin{tabular}{lr|r} 
& Frequency & Percentage \\
\hline Not & 5 & 27,8 \\
\hline Yes & 13 & 72,2 \\
\hline Total & 18 & 100,0 \\
\hline
\end{tabular}

It is important to highlight that the next analysis is directly related to the previous result, since the questioning is only valid for companies that have a specific area for logistics / supply chain issues, therefore, it was answered by the thirteen professionals who confirmed the existence of a specific sector logistics in the company in which they operate. Table 8 shows the activities that make up the scope of activities for which the specific area for logistics management and / or supply / supply chain management is responsible, and the thirteen companies that confirmed the existence of such area were once again considered. On this, it can be seen that by $92.3 \%$ of the companies evidenced the transport management is in its scope. Such significance given to transport can be associated with the importance of such activity in relation to logistics activities, since in addition to be a primary activity it is also, in most organizations, the largest share of logistics costs (Ballou, 2012; Faria; Costa, 2007).

Next, we highlight the supply and distribution logistics, which are present in $84.6 \%$ of the logistic scopes of those companies in question. According to Bowersox and Closs (2009), the main objective of the supply / supply is to support production, being that by providing timely purchases at the lowest total cost, it guarantees the organization advantages such as better performance of deadlines and higher satisfaction of customers. The distribution, in turn, can be characterized by the availability of the products to the clients, being they intermediate or final; it can soon add values of time and place to products, one of the goals of logistics management (Ballou, 2006).

Table 8. Activities belonging to the scope of the logistics area

\begin{tabular}{|c|c|c|c|}
\hline & Frequency & $\begin{array}{c}\text { Total } \\
\text { responses } \\
\text { analysed }\end{array}$ & $\begin{array}{l}\text { Perce } \\
\text { ntage }\end{array}$ \\
\hline Logistics Supply & 11 & 13 & 84,6 \\
\hline Logistics Supply & 11 & 13 & 84,6 \\
\hline Factory Logistics & 8 & 13 & 61,5 \\
\hline Reverse logistic & 4 & 13 & 30,8 \\
\hline Customer Relationship Management & 6 & 13 & 46,2 \\
\hline Establishing levels of customer service & 7 & 13 & 53,8 \\
\hline Transportation Management & 12 & 13 & 92,3 \\
\hline Inventory control and maintenance & 9 & 13 & 69,2 \\
\hline Processing and order fulfilment & 9 & 13 & 69,2 \\
\hline Storage & 9 & 13 & 69,2 \\
\hline Material Handling & 6 & 13 & 46,2 \\
\hline Supply management / purchases & 8 & 13 & 61,5 \\
\hline Packaging development & 2 & 13 & 15,4 \\
\hline Supplier relationship management & 5 & 13 & 38,5 \\
\hline $\begin{array}{c}\text { Planning and scheduling demand, sales, } \\
\text { production, inventory, purchasing and } \\
\text { distribution }\end{array}$ & 8 & 13 & 61,5 \\
\hline Exports & 7 & 13 & 53,8 \\
\hline Imports & 2 & 13 & 15,4 \\
\hline Logistics solutions design & 8 & 13 & 61,5 \\
\hline
\end{tabular}

The following two analyses pertain to the third section of the interview questions, which address outsourcing. Logistics outsourcing is worth mentioning, since it has advantages such as: it allows the company to maintain focus on the main business; reduces costs; can transform fixed costs into variable costs; increases the flexibility, efficiency and productivity of logistics processes; access to state-of-the-art technology; reduces investment in fixed assets; increases geographic coverage; makes it possible for the organization to enter into unfamiliar or unconquered 
markets; replaces the storage area by production area; improves customer service; acquired knowledge and know-how and reduced labour problems (Rabinovich et al., 1999; Hitt, 2002; Kakabadse and Kakabadse, 2000). The first question about outsourcing was about the existence of activities related to logistics and / or supply chain management in the companies in which the interviewed professionals work, which generated the results shown in Table 9 . More than $72 \%$ of the companies related to the respondents have outsourced logistics activities.

Table 9. Representativeness about the existence of outsourced logistics activities

\begin{tabular}{lr|r} 
& Frequency & \multicolumn{1}{c}{ Percentage } \\
\hline Not & 5 & 27,8 \\
\hline Yes & 13 & 72,2 \\
\hline Total & 18 & 100,0 \\
\hline
\end{tabular}

The following observations are related to the questions in the fourth section of the interview, which aims to understand the professionals' knowledge about the existence of trade-offs between costs related to logistics. Table 10 shows that on a scale of one to five, with "1" referring to "Intensely propagated" and "5" referring to "Not propagated", in $44.4 \%$ of companies referring to respondent professionals, it is intensely propagated that the logistic costs impact the economicfinancial performance of the organization. None of the respondents stated that this idea was not disseminated, which is important for the industry when considering the importance of logistics costs to the total costs of an organization and consequently its economic and financial performance (Ballou, 2006; Porter, 1980).

Table 10. Level of propagation concerning the impacts that logistics and their costs have on the economic and financial performance of companies

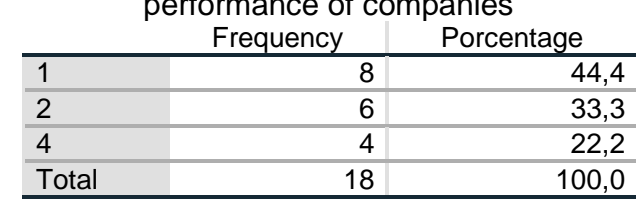

The next analysis identified the knowledge of logistics professionals in relation to what is really about the trade-offs of logistics costs and the dissemination made by companies in which they work on the definition and application of cost trade-offs in the face of logistics activities and / or the supply chain. The results refer to the answers to the question asked, in which the term trade-off was not used, but the definition of the same, when questioning about the compensatory exchanges between costs and / or level of service.

The scale used was the same one used in the previous analysis, where "1" refers to "Intensely propagated" and "5" to "Not propagated". It can be seen from Table 11 that most of them were defined "2" as the level of propagation on compensatory exchanges in the company in which it operates. It is also inferred that some of the professionals defined as "4" (16.7\%) and "5" (5.6\%) the level of propagation regarding compensatory trade related to logistics costs, which shows that there is still a deficiency the dissemination of the definition and real application of trade-offs of logistics costs in the analysed sector.

Table 11. Level of propagation due to the existence of compensatory cost changes, the increase in the cost of a given logistic activity can be offset by the increase in revenues as a consequence of the increase in the level of customer service or the reduction in the cost of other logistics activity, and vice versa

\begin{tabular}{|l|r|r|} 
& Frequency & Percentage \\
\hline 1 & 2 & 11,1 \\
\hline 2 & 7 & 38,9 \\
\hline 3 & 5 & 27,8 \\
\hline 4 & 3 & 16,7 \\
\hline 5 & 1 & 5,6 \\
\hline Total & 18 & 100,0 \\
\hline
\end{tabular}

The analysis that follows aims to identify the level of propagation on the impacts of the compensatory exchanges on the total costs of the organization. Lambert and Armitage (1979) point out that due to the existence of trade-offs, the reduction of some costs invariably leads to an increase in other costs, which negatively or positively impacts the total cost of the company, according to the quality of the management of compensation between these costs.

Table 12 shows the frequency referring to the answers of the professionals interviewed. It is emphasized that the same scale of previous issues was used, where " 1 " refers to "Broadly disseminated" and "5" to "Not widespread". It can be seen that most of them focus on the intermediate levels of propagation, with only two professionals saying they are widely propagated, and one practitioner stated that such an idea is not propagated in their organization.

There are also shortcomings in the relationship between compensatory trade and total cost with regard to the knowledge of the professionals emphasized.

Table 12. Level of spread of the idea that compensatory cost changes can determine the formation of the total cost

\begin{tabular}{l|r|r|} 
& Frequency & Porcentage \\
\hline 1 & 2 & 11,1 \\
\hline 2 & 6 & 33,3 \\
\hline 3 & 5 & 27,8 \\
\hline 4 & 4 & 22,2 \\
\hline 5 & 1 & 5,6 \\
\hline Total & 18 & 100,0 \\
\hline
\end{tabular}

The next analysis is considerably related to the previous one, since it seeks to identify the level of knowledge of logistics professionals about the fact that individual cost reduction can generate an increase in total logistics costs.

As mentioned before, the existence of compensatory trade-offs between costs related to logistics activities, causes the increase or decrease in a specific cost to change the total cost, and according to Gopal and Cypress (1993) the concept of total cost implies understanding that no logistic cost can be improved, or even modified, without affecting other logistics costs and / or level of customer service.

Amaral and Guerreiro (2014) agree with this idea when stating that logistics management should not seek to 
minimize costs from an individual perspective and Lin et al. (2001) emphasize that logistics managers should, after assessing the costs of activities, seek ways to optimize total cost.

The Table 13 shows that the greater part of the professionals interviewed have an intermediate level of knowledge about the reality emphasized by the question, which means, it is only three of them who affirm that such an idea is widely disseminated, nevertheless it is worth emphasizing that none of the professionals said not to be disseminated by the company in which it operates. It is important to note that the scale is "1" for "Broadly disseminated" and "5" for "Not widespread".

Table 13. Level of dissemination of the idea that individual cost reduction can increase total logistic cost

\begin{tabular}{lr|r} 
& Frequency & Porcentage \\
\hline 1 & 3 & 16,7 \\
\hline 2 & 5 & 27,8 \\
\hline 3 & 4 & 22,2 \\
\hline 4 & 6 & 33,3 \\
\hline Total & 18 & 100,0 \\
\hline
\end{tabular}

The question that gave rise to the following analysis refers to the existence of pressure for individual cost cuts that negatively impact the total cost or level of customer service in the day-to-day of the organization in which the interviewed professionals work.

This analysis is important in the investigation of effective business practices in the face of theoretical knowledge about compensatory cost changes. The scale used is characterized by: "1" refers to "Widely perceived" and "5" to "Never perceived".

The results evidenced by Table 14 show that, despite the existence of studies that prove the negative reality of the individual cost cut there is a certain dissemination of this idea by the companies, when analysed the realities practiced in the day-to-day basis show that the theory is not applied in its entirety.

None of the professionals discarded the existence of pressure by individual cuts and $11.1 \%$ of them perceive the wide and constant existence of such pressure.

Table 14. Level of perception of the existence of pressure due to individual cost cuts that increase total cost or worsen the level of service offered to the customer

\begin{tabular}{l|r|r} 
& Frequency & Porcentage \\
\hline 1 & 2 & 11,1 \\
\hline 2 & 4 & 22,2 \\
\hline 3 & 7 & 38,9 \\
\hline 4 & 5 & 27,8 \\
\hline Total & 18 & 100,0 \\
\hline
\end{tabular}

The following analysis concerns the fifth session of questions and deals with compensatory exchanges considered relevant to the organization in which they operate, that is, those that are analysed more frequently and have a greater impact on economic and financial performance.

Only the selected trade-offs will be approached, referring to each activity, as shown in Table 15.
Table 15. Compensatory exchanges considered relevant

\begin{tabular}{|ccc|c|c} 
Cost 1 or factor 1 & Cost 2 or factor 2 & $\begin{array}{c}\text { Answers } \\
\text { analysed } \\
\text { (total) }\end{array}$ & Frequency & Percentage \\
\hline $\begin{array}{c}\text { Level of } \\
\text { customer } \\
\text { service }\end{array}$ & Transport cost & 18 & 8 & $44,4 \%$ \\
\hline $\begin{array}{c}\text { Order } \\
\text { processing cost }\end{array}$ & $\begin{array}{c}\text { Demand forecast } \\
\text { cost }\end{array}$ & 18 & 7 & $38,9 \%$ \\
\hline $\begin{array}{c}\text { Inventory } \\
\text { maintenance } \\
\text { Cost }\end{array}$ & $\begin{array}{c}\text { Storage cost and } \\
\text { Demand forecast } \\
\text { cost }\end{array}$ & 18 & $\begin{array}{c}5 \text { each } \\
\text { costs } \\
\text { combinatio } \\
\text { n }\end{array}$ & $\begin{array}{c}27,8 \% \text { each } \\
\text { costs } \\
\text { combinatio } \\
n\end{array}$ \\
\hline $\begin{array}{c}\text { Demand } \\
\text { forecasting cost }\end{array}$ & $\begin{array}{c}\text { Inventory } \\
\text { maintenance cost } \\
\text { and Storage cost }\end{array}$ & 18 & $\begin{array}{c}5 \text { each } \\
\text { costs } \\
\text { combinatio } \\
n\end{array}$ & $\begin{array}{c}27,8 \% \text { each } \\
\text { costs } \\
\text { combinatio } \\
n\end{array}$ \\
\hline $\begin{array}{c}\text { Transport cost } \\
\text { maintentonce cost }\end{array}$ & 18 & 6 & $33,3 \%$ \\
\hline $\begin{array}{c}\text { Storage Costs } \\
\text { Demand Forecast } \\
\text { Costs }\end{array}$ & 18 & 4 & $22,2 \%$ \\
\hline Acquisition & Storage Costs & 18 & 4 & $22,2 \%$ \\
\hline costs & Acquisition costs & 18 & 5 & $27,8 \%$ \\
\hline Packaging costs & Packaging costs & 18 & 7 & $38,9 \%$ \\
\hline $\begin{array}{c}\text { Reverse } \\
\text { logistics costs }\end{array}$ & & & \\
\hline
\end{tabular}

The first compensatory exchange mentioned relates to the level of service offered to customers. It is noticed that most respondents emphasize the analysis between the level of service and the cost of transportation (44.4\%). Such emphasis is justified, as discussed by Chopra and Meindl (2003), by the fact that customer responsiveness depends on the time the company takes to meet the requests; for example, small batch deliveries required to promptly send orders to consumers do not provide economies of scale and lead to high transport costs. By contrast, temporary aggregation combines demands over time and delays deliveries, which reduces responsiveness and decreases service levels, but enables economies of scale to be reduced and transport costs are also reduced. Lee and Billington (1992) also point out the relationship between the service level and the mode of transport used, with modalities characterized by long lead times, although they are less expensive than fast transport means, offer low customer responsiveness, which results in a low level of service. Regarding the modalities, the National Statistical Institute (INE) states that the main mode used in Portugal is the road modal, which according to Ballou (2009), Bowersox and Closs (2006), is characterized by considerable flexibility, however it has high costs.

When emphasizing the Portuguese food sector, Marcelino (2011) points out that both light and heavy road transport are used, depending on the type of cargo. In addition, it states that vehicles must be properly equipped with the necessary infrastructures to guarantee the quality and safety of the products. The Code of Good Practices for the Transport of Foods of the Association of Restoration and Similar Products of Portugal (ARESP) requires that vehicles with food transport infrastructure must be in good repair and have adequate structures and components that guarantee quality, safety and customer satisfaction, which increases the costs related to the activity.

With respect to the costs of order processing, the tradeoff most frequently pointed out is related to the demand 
forecasting costs, with $38.9 \%$ representing the answers obtained. According to Jain (2004), the imprecise demand forecast results in losses in the performance of the order processing, which means, when oversized it induces processing that will not be received and that should not even have its preparation started, in contrast, the forecast of undersized demand triggers unplanned actions and processing. On the other hand, processing of improper orders results in delays in receiving and transmitting information, which minimizes the possibility of working with short production planning cycles, increases the time horizon and increases demand forecasting errors (Lee; Billington, 1992).

The next compensatory exchanges to be addressed relate to inventory maintenance costs. As for such costs, the professionals pointed out trade-offs as more relevant to the organization, which confronted them with costs of forecasting demand and storage costs, with $27.8 \%$ each. On the compensatory trade-offs between inventory maintenance and demand forecasting, Jain (2004) shows that when accurate forecasts of demand are made, it is possible to minimize errors, as well as to maintain only the inventories that are really necessary. Still further, the author states that the better the forecast of demand, the less obsolete inventories are maintained, and the less costs associated with capital, service, storage and the risk of inventory maintenance are incurred. On the other hand, the precision of demand forecasting is related to the adopted models, and the greater the complexity of the models, the greater the cost tends to be. Concerning the trade-offs between inventory maintenance costs and storage costs, Maister (1976) shows that although such costs are generally proportional, as the number of warehouses is increased, the security inventories and that the larger the inventory, the greater the need for warehouses; it is possible to identify compensatory exchanges between them. On this, Lambert and Stock (1992) show that if discounts are offered by the allocation or quantity of warehouses of the same lessee, there may be a reduction of storage costs; however, it is important to highlight that the cost of inventory does not follow such behaviour and grows with each warehouse added.

It is important to emphasize that the storage of food products requires certain special care, which generates costs and also expands the need to analyse them. Marcelino (2011) emphasizes in his studies that due to the fact that each type of food product has an expiration date and requires specific care and agrees with the approach of Bowersox and Closs (1996), it is of paramount importance not to generalize one type of warehouse layout, which depends on the type of products to be stored and the conditions required by them. The special care required by the food logistics sector also raises analytical perspectives on the importance of due order processing, demand forecasting, and inventory maintenance, since the organization and sizing of the entire warehouse stock and configuration must take into consideration and demand of the products, which is linked to the processing of orders, and the perishability of food is a crucial factor for maintaining quality and is directly related to the time and conditions that it will remain stocked.

Regarding the changes related to the demand forecasting costs, the respondents pointed out the differences between them and inventory maintenance costs as well as storage costs, with a selection of $27.8 \%$ from the eighteen responses. The trade-offs between demand forecasting and inventory maintenance costs have already been addressed in the previous analysis. In terms of demand forecasting and storage costs, Jain (2004) points out that when an imprecise and oversized demand forecast is made, the organization starts buying products in exaggeration, which will require more storage space, greater the necessity of labour, reception equipment, storage, handling and handling of products. If storage and material handling are considered justified only if added value is added to the products, it can be said that the imprecision in the forecast of demand has the consequence of expendable storage costs.

With a representativeness of $33.3 \%$ in relation to the eighteen answers obtained about the trade-offs related to transportation costs, it is worth noting the compensatory changes between them and the maintenance costs of inventories. On this, Chow (2008), Bhatnagar and Teo (2009), Lambert and Stock (1992) agree that the time by which inventories are found in organizations are dependent on transport and that it is influenced by the configuration of the logistics network. These authors show that by making use of timely transports, the company becomes able to keep inventories for a shorter period in the vehicles, which guarantees certainty and results in the reduction of safety stocks. These actions result in lower inventory maintenance costs, which may offset the increase in transportation costs. The reverse is also pointed out by the authors, and slow transport, although characterized by less expressive costs, it makes more robust security stocks necessary, and consequently a long inventory maintenance period. Regarding the trade-offs related to storage costs, the respondents once again emphasized the existing ones and demand forecasting costs, with a $22.2 \%$ share. The comments on the compensatory exchange in question have already been made earlier.

As for the trade-offs which address the acquisition costs, the respondents highlight $(22.2 \%)$ those that face acquisition and storage. Amaral (2012) states that the space demanded for storage is dependent on the quantity of products purchased, and purchases with large quantities assist in the negotiation of discounts and result in a reduction of acquisition costs, that is, fewer personnel, equipment and systems necessary for the activity, however, also results in an increase in the cost of storage. On the other hand, purchases of small quantities induce the reduction of storage costs, but require high acquisition costs, through the constant need for labour, infrastructure and systems applied to the activity in the remittance of the various orders.

When packaging costs were emphasized, the respondents pointed out the compensatory exchanges between them and the acquisition costs. Regarding this, 
Amaral (2012) makes it clear that packaging needs to be acquired and, thus, relate to the activity of acquisitions, and that returnable packaging demands a higher cost than non-returnable packaging, but dispenses or lessens demand for new purchases packaging (Reusable Packaging Association, 2008). According to Ferreira (2012), packaging is an important factor in food logistics, which helps to preserve the products and allows them to be delivered under the conditions required by the customer. It is also worth noting that according to the type of product specifications are required to ensure their quality and safety, which influences costs.

Finally, when emphasizing the costs of reverse logistics, the interviewees point out the trade-offs that confront the costs of packaging. Vernuccio et al. (2010) state that the logistics functions of the packages directly impact on the efficiency of reverse logistics, since when standardized and well dimensioned, they facilitate the handling and optimize the space utilization of the reverse installations. In addition, the traceability made possible by the information found on the packaging reduces the risk of loss, thus ensuring greater safety in the return process. On the other hand, the greater the use of returnable packaging, the greater the use of reverse logistics.

\section{FINAL CONSIDERATIONS AND FUTURE RESEARCH}

With the objective of analysing the logistic professional knowledge and how trade-offs of logistics costs impact the economic-financial performance of Portuguese companies in the food sector, the study in question showed that, despite the existence of compensatory exchanges, the search for individual and momentary results, causes that they do not act according to the theoretical proposals. One can also perceive some inconsistencies in the knowledge of the term trade-offs related to logistic costs and their real definition, which means, the percentage of professionals who claimed to have knowledge on this subject when were asked about the term was higher than the portion that confirmed when questioned using the meaning. The identification of the compensatory exchanges, considered relevant for the professionals, brings a certain perspective about the activities that, when their costs and benefits are confronted, presents characteristics to be evaluated for the design of logistics solutions and decision making in the emphasized sector.

The studies carried out also highlighted the importance of logistics for the food sector, which, by adding value of time and place through the proper performance of their activities, guarantee higher quality and safety for food, which is determinant for the achievement of customer satisfaction and organizational success. It can be noticed that in relation to the questions formulated to carry out the study, the first one was answered by pointing out the costs that are most commonly confronted, that is to say, its trade-offs are considered relevant. Regarding the second questioning and as it was said before, there was controversy regarding the effective knowledge about the meaning and application of logistic cost trade-offs. Regarding the hypotheses formulated, the first one was confirmed, since individual cuts occur in organizations, and the pressure for momentary results is the main cause of this. The second hypothesis can be denied by the results of the research, since most of the professionals claimed to have knowledge and the term to be propagated in the companies in which they work. As gaps in the present study, we identify the mathematical analysis of logistics costs to prove the trade-offs relevance pointed out by professionals. As future studies, such analysis is proposed, as well as the extension of the study to other productive segments, to identify the level of knowledge of logistics professionals in a more general way.

\section{ACKNOWLEDGMENTS}

This work was supported by the CIDEM, R\&D unit funded by the FCT - Portuguese Foundation for the Development of Science and Technology, Ministry of Science, Technology and Higher Education [UID/EMS/0615/2016]; and the Federal Institute of Education, Science and Technology of Minas Gerais [ARINTER/PRPPG/PROEX/IFMG/138/2016]

\section{REFERENCES}

[1] Adenso-Díaz, B., Lozano, S., and Moreno, P. (2016). How the environmental impact affects the design of logistics networks based on cost minimization. Transportation Research Part D: Transport and Environment, 48, 214-224. http://doi.org/10.1016/j.trd.2016.08.022

[2] Amaral, J. V. (2012). Trade-offs de custos logísticos (Doctoral dissertation, Universidade de São Paulo, Brazil).

[3] Amaral, J., and Guerreiro, R. (2014). Conhecimento e Avaliação dos Trade-offs de Custos Logísticos: um Estudo com Profissionais Brasileiros. Revista Contabilidade \& Finanças, 25(65), 111-123. http://doi.org/https://dx.doi.org/10.1590/S151970772014000200003

[4] Ballou, R. H. (2009). Gerenciamento da Cadeia de Suprimentos-: Logística Empresarial. Bookman Editora.

[5] Ballou, R. H. (2012). Logística empresarial: transportes, administração de materiais e distribuição física. 1. ed. São Paulo: Atlas.

[6] Ballou, R. H. (2006). A evolução e o futuro da logística e do gerenciamento da cadeia de suprimentos. Production, 16(3), 375-386. https://dx.doi.org/10.1590/S0103-65132006000300002

[7] Bhatnagar, R., and Teo, C.-C. (2009). Role of logistics in enhancing competitive advantage: A value chain framework for global supply chains. International Journal of Physical Distribution \& Logistics Management, 39(3), 202-226. http://doi.org/10.1108/09600030910951700

[8] Blecic, I., Cecchini, A., and Trunfio, G. A. (2007). A decision support tool coupling a causal model and a multi-objective genetic algorithm. Applied Intelligence, 26(2), 125-137. https://doi.org/10.1007/s10489-006-0009-z

[9] Bleger, J. (1971). Cuestiones metodológicas del psicoanálisis. In D. Ziziensky (Ed.), Métodos de investigación em psicologia y psicopatologia (pp.113-131). Buenos Aires: Edicones Nueva Visión.

[10] Bowersox, D. J., Closs, D. J., Cooper, \& M. B., Bowersox, J. C. (2014). Gestão logística da cadeia de suprimentos. Porto Alegre: Bookman.

[11] Bowersox, D. J., and Closs, D. J. (2001) Logística Empresarial. O Processo de integração da cadeia de suprimento. São Paulo: Atlas.

[12] Bowersox, D.J., and Closs, D.J. (2009). Logística empresarial: o processo de integração da cadeia de suprimento. São Paulo: Atlas.

[13] Castiglioni, J. A. D. M., and Nascimento, F. C. D. (2014). Custos de processos logísticos. São Paulo: Erica. 
[14] Cerchione, R., and Esposito, E. (2016). A systematic review of supply chain knowledge management research: State of the art and research opportunities. International Journal of Production Economics, 182 https://doi.org/10.1016/j.ijpe.2016.09.006

276-292.

5] Chen, J. M., and Chen, T. H. (2005). The multi-item replenishment problem in a two-echelon supply chain: the effect of centralization versus decentralization. Computers \& Operations Research, 32(12), 3191-3207. https://doi.org/10.1016/j. cor.2004.05.007

[16] Cheong, T., and Song, S. H. (2013). The value of information on supply risk under random yields. Transportation Research Part E, 60, 27-38. http://dx.doi.org/10.1016/j.tre.2013.09.006

[17] Chopra, S., and Meindl, P. (2003). Gerenciamento da Cadeia de Suprimento, estratégia, planejamento e operação. São Paulo: Prentice Hall.

[18] Chow, G. (2008). Getting back to basics. Canadian Transportation Logistics, 111 (10), 40.

[19] Christopher, M. (2016). Logistics \& supply chain management. Pearson UK.

[20] Christopher, M., and Ryals, L. (1999). Supply chain strategy: Its impact on shareholder value. The International Journal of Logistics Management, 10(1), 1-10.

[21] Craig, R. J. (1991). Processo Clínico de Entrevista. Em Entrevista Clínica e Diagnóstica. (pp 25-43). Porto Alegre: ARTMED.

[22] Esper, T. L., Ellinger, A. E., Stank, T. P., Flint, D. J., and Moon M. (2010). Demand and supply integration: a conceptua framework of value creation through knowledge management. Journal of the Academy of marketing Science, 38(1), 5-18. https://doi.org/10.1007/s11747-009-0135-3

[23] Fang, Y., and Ng, S. T. (2011). Applying activity-based costing approach for construction logistics cost analysis. Construction Innovation, 11(3), https://doi.org/10.1108/14714171111149007

[24] Faria, A.C. and Costa, M.F.G. (2007). Gestão de custos logísticos. 1 ed. São Paulo: Atlas, 2007.

[25] Ferreira, S. S. L. (2012). Gestão de armazéns: implementação de um sistema de picking na indústria alimentar. Santarém,2012. (Master's dissertation, Santarém).

[26] Fołta, J. T., Godlewska, Ł., and Godlewski L. (2013). Wycena i ujawnianie zapasów w prawie krajowym i międzynarodowym, SKwP, Warszawa

[27] Gopal, C., and Cypress, H. (1993). Integrated distribution management: competing on customer service, time, and cost. Homewood: Irwin.

[28] Graungaard Pedersen, S., Zachariassen, F., and Stentoft Arlbjørn, J. (2012). Centralisation vs de-centralisation of warehousing: A small and medium-sized enterprise perspective. Journal of Small Business and Enterprise Development, 19(2), https://doi.org/10.1108/14626001211223946

[29] Gunasekaran, A., and Kobu, B. (2007). Performance measures and metrics in logistics and supply chain management: a review of recent literature (1995-2004) for research and applications. International journal of production research, 45(12), 2819-2840. https://doi.org/10.1080/00207540600806513

[30] Hall, R. H. (1984). Organizações: estrutura e processos. 3. ed. Rio de Janeiro: Prentice-Hall do Brazil.

[31] Hensher, D. A., and Puckett, S. M. (2008). Power, concession and agreement in freight distribution chains: subject to distancebased user charges. International Journal of Logistics, 11(2), 81100. https://doi.org/10.1080/13675560701530040

[32] Hitt, M.A., Ireland, R.D., and Hoskisson, R.E. (2002) Administração Estratégica: Competitividade e Globalização. Translation by José Carlos Barbosa dos Santos and Luiz Antonio Pedroso Rafael. São Paulo: Pioneira Thomson Learning.

[33] Hult, G. T. M., Ketchen, D. J., Cavusgil, S. T., and Calantone, R. J. (2006). Knowledge as a strategic resource in supply chains. Journal of operations management, 24(5), 458-475. https://doi.org/10.1016/j.jom.2005.11.009

[34] Jackson, G. C., Stoltman, J. J., and Taylor, A. (1994). Moving beyond trade-offs. International Journal of Physical Distribution \& Logistics Management, 24(1), https://doi.org/10.1108/09600031211269749
[35] Jain, C. L. (2004). How to measure the cost of a forecast error. The Journal of Business Forecasting Methods \& Systems. Flushing, 22 (4), 29-30.

[36] Janssen, M. (2004). Insights from the introduction of a supply chain co-ordinator. Business Process Management Journal, 10(3) 310.https://doi.org/10.1108/14637150410539704

[37] Jong, G., Kouwenhoven, M., Ruijs, K., van Houwe, P., and Borremans, D. (2016). A time-period choice model for road freight transport in Flanders based on stated preference data. Transportation Research Part E: Logistics and Transportation Review, 86, 20-31. https://doi.org/10.1016/j.tre.2015.12.004

[38] Kakabadse, N., and Kakabadse, A. (2000). Critical review Outsourcing: a paradigm shift, Journal of Management Development, 19 (8), https://doi.org/10.1108/02621710010377508

[39] Kator, C. (2007). Inventory costs rise dramatically. Modern Materials Handling: Warehousing Management Edition. Framingham, 62 (07).

[40] Ketchen, D. J., and Hult, G. T. M. (2007). Bridging organization theory and supply chain management: The case of best value supply chains. Journal of Operations Management, 25(2), 573580. https://doi.org/10.1016/j.jom.2006.05.010

[41] Kościelniak, H. (2011). Logistics costs in cement industry. Gospodarka Materiałowa i Logistyka, (12), 54-60.

[42] Lakshman, C., and Parente, R. C. (2008). Supplier-focused knowledge management in the automobile industry and its implications for product performance. Journal of Management Studies, 45(2), 317-342. https://doi.org/10.1111/j.14676486.2007.00743.x

[43] Lambert, D. M., and Armitage, H. M. (1979). Distribution costs: the challenge. Management Accounting, 60(11), 33-45.

[44] Lambert D. M., and Stock, J. R. (1992). Strategic logistics management. 3. ed. Irwin/Mcgraw-Hill, Boston.

[45] Lee, H. L.; \& Billington, C. (1992). Managing supply chain inventory: pitfalls and opportunities. Sloan Management Review. Cambridge, v. 33, n. 03, p. 64-73, spring.

[46] Lin, B., Collins,J., and Su, R.K. (2001) Supply chain costing: an activity-based perspective. International Journal of Physical Distribution \& Logistics Management, 31 (10), 702-713. https://doi.org/10.1108/EUM0000000006286

[47] Liu, L., Chen, G., and Niu, X. (2015). Game analysis of the knowledge sharing mechanism for the supply chain collaborative innovation. Journal of Industrial Engineering and Management, 8(1), 152-169. http://dx.doi.org/10.3926/jiem.1368

[48] Liu, Y., Huang, Y., Luo, Y., and Zhao, Y. (2012). How does justice matter in achieving buyer-supplier relationship performance?. Journal of Operations Management, 30(5), 355367. https://doi.org/10.1016/j.jom.2012.03.003

[49] Maister, D. H. (1976). Centralization of inventories and the square root law. International Journal of Physical Distribution \&

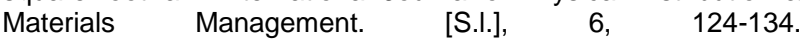
https://doi.org/10.1108/eb014366

[50] Marçal, J. (2006). A influência da logística na competitividade das empresas: o caso das empresas grossistas de distribuição em Portugal. (Doctorial dissertation,Universidade LusíadaFaculdade De Ciências Da Economia e da Empresa, Lisboa, Portugal).

[51] Marcelino, L. F. H. (2001). A logística do frio na cadeia de abastecimento agro-alimentar: abordagem qualitativa. (Master's dissertation, Universidade da Beira Interior, Portugal).

[52] Mclntyre, S.H., and Ryans, A.B. (1983). Task effects on decision quality in travelling salesperson problems. Organizational Behavior and Human Performance 32, 344- 369. https://doi.org/10.1016/0030-5073(83)90155-1

[53] Mentzer, J. T., Flint, D. J., and Hult, G. T. M. (2001). Logistics service quality as a segment-customized process. Journal of marketing, 65(4), https://doi.org/10.1509/jmkg.65.4.82.18390

[54] Mintzberg, H. (1995). Criando organizações eficazes: estruturas em cinco configurações. São Paulo: Atlas.

[55] Moreira D. A. (2002). A natureza da pesquisa qualitativa - O método fenomenológico na pesquisa. São Paulo: Pioneira Thompson.

[56] Murphy, P., and Poist, R. F. (2007). Skill requirements of senior-level logisticians: a longitudinal assessment. Supply 
Chain Management: An International Journal, 12 (6), 423-431. https://doi.org/10.1108/13598540710826353

[57] Nowakowska-Grunt, J., and Новаковска-Грунт Й. (2013). Strategies for enterprises of logistics market in Poland and Europe. http://ir.kneu.edu.ua:8080/handle/2010/8536

[58] Oliveira S. L. (2001). Tratado de metodologia científica: projetos de pesquisas, TGI, TCC, monografias, dissertações e teses. São Paulo: Pioneira.

[59] Paula, G. M. (2007). Estruturas organizacionais: o papel do gestor de nível intermediário. (Master's dissertation, Faculdade de Ciências Empresariais, Universidade FUMEC. Belo Horizonte, Brazil).

[60] Porter, M. (1980). Competitive Strategy: Techiniques for Analysing Industries and Competitors. New York: The Free Press.

[61] Pozo, H. (2016). Administração de recursos materiais e patrimoniais: uma abordagem logística. Editora Atlas SA.

[62] Presutti Jr, W. D., and Mawhinney, J. R. (2007). The Supply ChainFinance Link. Supply Chain Management Review, 11 (6), 32-38.

[63] Rabinovich, E., and Windle, R., Dresner,M., \& Thomas, C. (1999). Outsourcing of integrated logistics functions: An examination of industry practices. International Journal of Physical Distribution \& Logistics Management, 29 (6)

353-374. https://doi.org/10.1108/09600039910283587

[64] Randall, W. S., and Farris, T. M. (2009). Supply chain financing: using cash-to-cash variables to strengthen the supply chain. International Journal of Physical Distribution \& Logistics Management, 39(8), https://doi.org/10.1108/09600030910996314

[65] Rao, P., and Holt, D. (2005). Do green supply chains lead to competitiveness and economic performance?. International journa of operations \& production management, 25(9), 898 916. https://doi.org/10.1108/01443570510613956

[66] Reusable Packaging Association. (2008) A cost comparison mode for Reusable Transport Packaging.

[67] Richardson, H. L. (1993). Power Up The Value Of Logistics. Transportation \& Distribution, 34 (3), 29-34.

[68] Sánchez, R. J., Hoffmann, J., Micco, A., Pizzolitto, G. V., Sgut, M. and Wilmsmeier, G. (2003). Port efficiency and international trade: port efficiency as a determinant of maritime transport costs. Maritime economics \& logistics, 5(2), 199-218. http://dx.doi.org/10.1057/palgrave.mel.9100073

[69] Selltiz, C. (1974). Métodos de pesquisa nas relações sociais. EPU.

[70] Slone, R. E, et al. (2007). Are you the weakest link in your company's supply chain?. Harvard Business Review. Boston, 85 (9) 116-127. https://hbr.org/2007/09/are-you-the-weakest-link-in-yourcompanys-supply-chain

[71] Sobotka, A., and Czarnigowska A. (2005), Analysis of supply system models for planning construction project logistics. Journal of Civil
Engineering and Management, 6 (1), 73-82. https://doi.org/10.1080/13923730.2005.9636335

[72] Stępień, M., Łęgowik-Świącik, S., Skibińska, W., and Turek, I. (2016) Identification and Measurement of Logistics Cost Parameters in the Company. Transportation Research Procedia, 16, 490-497. https://doi.org/10.1016/j.trpro.2016.11.046

[73] Sum, C. C., Shih-Ju Kow, L., and Chen, C. S. (2004). A taxonomy of operations strategies of high performing small and medium enterprises in Singapore. International Journal of Operations \& Production Management, 24(3), https://doi.org/10.1108/01443570410519051

[74] Torabi, S. A., Baghersad, M., and Mansouri, S. A. (2015). Resilient supplier selection and order allocation under operational and disruption risks. Transportation Research Part E: Logistics and Transportation Review, 79,

$22-48$ https://doi.org/10.1016/j.tre.2015.03.005

[75] Vernuccio, M., Cozzolino, A., and Michelini, L. (2010). An exploratory study of marketing, logistics, and ethics in packaging innovation. European Journal of Innovation Management. Bradford, 13 (3), 333354. https://doi.org/10.1108/14601061011060157

[76] Walters, D. (1999). The implications of shareholder value planning and management for logistics decision making. International Journa of Physical Distribution \& Logistics Management, 29(4), 240-258. https://doi.org/10.1108/09600039910273966

[77] Walters, D. (2004). A business model for the new economy International Journal of Physical Distribution \& Logistics Management, $34 \quad 346-57$ https://doi.org/10.1108/09600030410533637

[78] Xu, S. X., Cheng, M., and Huang, G. Q. (2015). Efficient intermodal transportation auctions for B2B e-commerce logistics with transaction costs. Transportation Research Part B: Methodological, 80, 322-337. https://doi.org/10.1016/j.trb.2015.07.022

[79] Yang, J., Wong, C. W, Lai, K. H., and Ntoko, A. N. (2009). The antecedents of dyadic quality performance and its effect on buyersupplier relationship improvement. International Journal of Production Economics, 120(1),

243-251 https://doi.org/10.1016/j.ijpe.2008.07.033

[80] Zeng, A. Z., and Rossetti, C. (2003), Developing a framework for evaluating the logistics costs in global sourcing processes. Journal of Physical Distribution \& Logistics Management, 33 (9), 785-803. https://doi.org/10.1108/09600030310503334

[81] Zhu, Q., Sarkis, J., and Lai, K. H. (2013). Institutional-based antecedents and performance outcomes of internal and external green supply chain management practices. Journal of Purchasing and Supply Management, 19(2), 106-117. http://dx.doi.org/10.1016/j.pursup.2012.12.001

\title{
Analiza znanja o kompenzaciji troškova logistike: Studija sa portugalskim stručnjacima u prehrambenom sektoru
}

\author{
Ana Luiza Cordeiro Pereira, Alexandra Manuela Novais Almeida dos Santos Martins, Renata \\ Veloso Santos Policarpo, Maria Teresa Ribeiro Pereira
}

Primljen (16.05.2018.); Recenziran (29.06.2018.); Prihvaćen (03.09.2018.)

\begin{abstract}
Apstrakt
Logistika je važna oblast ekonomsko-finansijskog poslovanja kompanija, zbog čega je neophodno analizirati njihove troškove, kao i kompromise između njih. Stoga je ova studija, s ciljem analize znanja portugalskih stručnjaka logistike prehrambenog sektora u pogledu kompromisnih troškova logistike $i$ njihovog uticaja na ekonomsko-finansijske performanse organizacija, pokazala da postoje nedostaci u vezi sa ovom temom. Tokom strukturiranog intervjua i korišćenja softvera SPSS, studija pokazuje postojanje mana u praktičnoj primeni teorije kompromisa, kao što je pritisak menadžera za pojedinačno smanjenje troškova, i ukazuje na kompromise logističkih troškova koji se odnose na prehrambeni sektor. Ovi rezultati doprinose ekspanziji studija o ovoj oblasti, pored pružanja perspektive kompenzatornih razmena koje mogu doprineti donošenju odluka u vezi troškova vezanih za logističke aktivnosti.
\end{abstract}

Ključne reči: logistički troškovi; kompromisi logističkih troškova; ekonomsko-finansijska performansa; prehrambeni sektor; prehrambena logistika. 